\title{
Ranch Resource Differences Affecting Profitability of Crested Wheatgrass as a Spring Forage Source
}

\author{
KIMBERLY A. SPIELMAN AND RONALD L. SHANE
}

\begin{abstract}
A representative cow-calf ranch operation in Elko County, Nev., was modeled using a linear programming procedure to determine effects of selected ranch resource differences on profitability of seeding crested wheatgrass. Net present value (NPV) results suggest seeding crested wheatgrass as a spring forage can be a profitable investment if there are associated increases in calf weaning weights of $9.07 \mathrm{~kg}$ and increases in calving rates of 5 percentage points. Amount of meadow hayland, deeded range, and BLM forage available to the representative ranch were increased and decreased $50 \%$. NPV's of the crested wheatgrass investment are greater for ranches with excess meadow hay and excess deeded range. NPV's are lower for ranches with limiting resources of meadow hayland, deeded range, and BLM forage.
\end{abstract}

Herd size and profit potential on many western ranch operations are limited by availability of high quality, low cost early spring forage. Increased infestation of rangeland with low quality forage species may decrease the amount of spring forage produced. Overgrazing of the perennial grass community during the 1880 's destroyed much of the native understory, with degraded stands of sagebrush remaining (Young et al. 1979). Also, domination of rangeland by late maturing range species may delay early spring usage of the range. Given a permanent physical shortage of early spring forage, an operator may choose to buy hay, lease pasture, or graze other forage sources earlier than desired to maintain stand productivity. However, depending on costs and returns, it may be more profitable for the operator to maintain a smaller herd size and have excess ranch forage later in the grazing season.

One possible investment alternative to inadequate spring forage is to remove existing forage and seed the rangeland with an earlier maturing grass. The adaptability of crested wheatgrass (Agropyron desertorum) as a forage source on western range operations has been established, as more than 5 million ha have been seeded in the U.S. (Dewcy and Asay 1975). Crested wheatgrass has its high-

\footnotetext{
Authors are former research associate and associate professor, respectively, Department of Agricultural Economics, University of Nevada. Reno 89557-0004.

The United States Department of Agriculture provided partial funding for this study under a research agreement with Economic Reseach Service in cooperation with USDA ARS scientists located at the University of Nevada. Reno. The authors are grateful to USDA for its support.

Manuscript accepted January 10. 1985
}

est nutritional content in early spring (Rauzi 1975) and develops 2 to 3 weeks earlier than native grasses (Frischknecht et al, 1953). Successful crested wheatgrass stands have been established in most western states (Lloyd and Cook 1960, Robertson et al. 1970, Sharp 1970).

Much research has focused on the difference in animal production between grazing native range and grazing crested wheatgrass (Jeffries et al. 1967, Springfield and Reid 1967, Hart et al. 1983). Economic aspects of seeding as a range improvement have also been analyzed. Several studies have estimated returns to seeding based on the value of increased animal gains produced on seeded range versus native range. Kearl and Cordingly (1975), using budgeting techniques, determined that reseeding rangeland is a profitable investment for a cow-yearling operation, assuming increases in weaning weights and calving percentages. Those management practices which influence crested wheatgrass seeding profitability were identified by Godfrey (1975) in a study of various seeding utilization patterns. Relatively high economic returns from increased animal gains made on crested wheatgrass over time have been estimated for most grazing patterns in Idaho (Godfrey et al. 1979). Sonnemann (1982) concluded that seeding crested wheatgrass on a cow-calf operation is profitable even if weaning weights and calving percentages are unchanged, provided excess resources are available to enable cow herd size to increase.

Previous research has concentrated on the impact of various management practices on profitability of crested wheatgrass as a range improvement project. Effects of forage resource quantity differences among ranches upon profitability of removing sagebrush and planting crested wheatgrass have not been evaluated. Objectives of this study are: (1) determine if ceteris paribus differences from one ranch to another in amounts of meadow hayland, deeded forage, and public range forage will influence expected profitability of the range investment of seeding crested wheatgrass and (2) if differences exist, identify factors contributing to increased profitability.

\section{Procedure}

Linear programming (LP) ranch models were developed in this study to estimate the effect of different levels of 3 ranch resources 
on net returns to seeding crested wheatgrass. LP is frequently used as a research technique to determine economically efficient allocation of range resources (Woodworth 1973, D'Aquino 1974, Torell 1981). The LP technique allows simultaneous examination of resource and activity alternatives in an operation to determine the optimal combination of production activities. This mathematical procedure can maximize returns or minimize costs subject to a set of production constraints. LP has an advantage over total ranch budgeting in the reduced time by which a large number of production alternatives can be evaluated to achieve the single economically optimal solution in ranch resource use.

Recursive linear programming (RLP), a variation of linear programming, is the modeling procedure used in this study to enable sequential optimization of the ranch operation throughout the seeding establishment process. An RLP model is constructed and used in the same manner as an ordinary LP model (Day 1963). RLP, however, permits changes in resource levels and technical coefficients from one period to the next. An optimal solution for an unchanging production system is obtained from LP. RLP accounts for system differences between periods by utilizing optimal results from the previous time period. Modification of specified resource levels was thus made in this study during modeled transition periods between the initial operation and the final situation 5 years later, when crested wheatgrass seeding is a forage source and ranch adjustments are complete. Changes between periods in production coefficients, e.g., weaning weights and calving percentages, were also made where appropriate.

The RLP model constructed describes a representative cow-calf operation in Elko County, Nev. Elko County contains some of the State's most productive rangeland. Cost data, resources, and activities for the operation were based on information obtained from a panel of ranchers (Myer and Hackett 1982, USDA 1983). Return data were based on average Kansas City prices received 1979-1981 (Livestock and Meat Situation, USDA, 1979-81). Initial resource levels and activities of the model are shown in Table 1 . Initial herd size and production parameters are given in Table 2 .

This specific RLP model allocates available forage sources among alternative activities to maximize the objective function of annual net returns to variable costs, calculated as total sales minus

Table 1. Initial resource levels, yield, and graxing periods of representative ranch, Elko County, Nevada.

\begin{tabular}{lccc}
\hline \hline Resource & $\begin{array}{c}\text { Unit of } \\
\text { measure }\end{array}$ & Quantity & Yield \\
\hline $\begin{array}{l}\text { Mechanical harvesting: } \\
\begin{array}{l}\text { Meadow hayland } \\
\text { Dec. 15-Apr. 14 }\end{array}\end{array}$ ha (acres) & $524(1295)$ & $\begin{array}{c}2470 \mathrm{~kg} / \mathrm{ha} \\
(1.1 \mathrm{tons} / \mathrm{acre})\end{array}$
\end{tabular}

\section{Grazing:}

BLM rangeland:

$\begin{array}{llr}\text { Apr. 15-May 14 } & \text { AUM } & 532 \\ \text { May 15-June 14 } & \text { AUM } & 563 \\ \text { June 15-July 14 } & \text { AUM } & 780 \\ \text { July 15-Sept. 14 } & \text { AUM } & 900 \\ \text { Deeded rangeland: } & & \\ \text { Apr. 15-May 14 } & \text { AUM } & 50 \\ \text { May 15-June 14 } & \text { AUM } & 50 \\ \text { June 15-July 14 } & \text { AUM } & 100 \\ \text { July 15-Sept. 14 } & \text { AUM } & 412 \\ \text { Sept. 15-Oct. 31 } & \text { AUM } & 339\end{array}$

Meadow pastureland:

Nov. 1-Dec. $14 \quad$ AUM $407 \quad \begin{aligned} & 2.47 \mathrm{AUM} / \mathrm{ha} \\ & (1 \mathrm{AUM} / \mathrm{acre})\end{aligned}$

Meadow hayland aftermath:

Nov. 1-Dec. 14 AUM $917 \quad \begin{aligned} & 1.85 \mathrm{AUM} / \mathrm{ha} \\ & (.75 \mathrm{AUM} / \mathrm{acre})\end{aligned}$

Table 2. Stock count table.

\begin{tabular}{|c|c|c|c|}
\hline \multirow[b]{2}{*}{ Livestock class } & \multirow[b]{2}{*}{ Measure } & \multicolumn{2}{|c|}{ Quantity } \\
\hline & & Before seeding & After seeding \\
\hline $\begin{array}{l}\text { Weight: } \\
\text { Heifer weaners } \\
\text { Steer weaners } \\
\text { Cull cows } \\
\text { Cull bulls }\end{array}$ & $\begin{array}{l}\text { kg (lbs) } \\
\text { kg (lbs) } \\
\text { kg (lbs) } \\
\text { kg (lbs) }\end{array}$ & $\begin{array}{ll}161 & (355) \\
180 & (395) \\
420 & (925) \\
545 & (1,200)\end{array}$ & $\begin{array}{ll}170 & (375) \\
189 & (415) \\
420 & (925) \\
545 & (1,200)\end{array}$ \\
\hline $\begin{array}{l}\text { Production parameters: } \\
\text { Weaned calf rate } \\
\text { Replacement rate } \\
\text { Death loss-cows } \\
\text { Death loss-bulls } \\
\text { Bull-cow ratio }\end{array}$ & $\begin{array}{l}\% \\
\% \\
\% \\
\%\end{array}$ & $\begin{array}{r}.80 \\
.20 \\
.03 \\
.07 \\
1: 20\end{array}$ & $\begin{array}{r}.85 \\
.20 \\
.03 \\
.07 \\
1: 20\end{array}$ \\
\hline $\begin{array}{l}\text { Initial inventory: } \\
\text { Brood cows } \\
12 \text { mo. replacements } \\
24 \text { mo. replacements } \\
\text { Bulls }\end{array}$ & & $\begin{array}{l}\text { no. } \\
\text { no. } \\
\text { no. } \\
\text { no. }\end{array}$ & $\begin{array}{r}480 \\
125 \\
120 \\
30\end{array}$ \\
\hline
\end{tabular}

total variable costs. Table 3 shows per unit variable costs and per unit returns included in the model. Hired labor and operator labor for the ranch were included in the raise-cow-cost activity at $\$ 6.00$ per hour. An opportunity cost for the operator's management was not included. Other costs not included in the model were costs of horses, depreciation, taxes, interest, and insurance.

Table 3. Costs and returns for major representative ranch activities.

\begin{tabular}{|c|c|c|}
\hline Activity & Measure & Cost/unit (\$) \\
\hline $\begin{array}{l}\text { Cost: } \\
\text { Establish crested wheatgrass } 1 \\
\text { Grow and harvest meadow hay } \\
\text { Graze BLM rangeland } \\
\text { Graze deeded rangeland } \\
\text { Graze meadow pasture } \\
\text { Graze meadow hay aftermath } \\
\text { Purchase grass hay } \\
\text { Raise cow }{ }^{2} \\
\text { Lease private range }\end{array}$ & $\begin{array}{l}\text { ha } \\
\text { ha } \\
\text { AUM } \\
\text { AUM } \\
\text { AUM } \\
\text { AUM } \\
\text { kg } \\
\text { head } \\
\text { AUM }\end{array}$ & $\begin{array}{c}\$ 46.42 \\
62.30 \\
1.40 \\
0 \\
0 \\
0 \\
.09 \\
155.11 \\
5.70\end{array}$ \\
\hline $\begin{array}{l}\text { Return: } \\
\text { Sell weaner heifer } \\
\text { Sell weaner steer } \\
\text { Sell cull cow } \\
\text { Sell cull bull }\end{array}$ & $\begin{array}{l}\mathrm{kg} \\
\mathrm{kg} \\
\mathrm{kg} \\
\mathrm{kg}\end{array}$ & $\begin{array}{c}1.34 \\
1.65 \\
.95 \\
1.17\end{array}$ \\
\hline
\end{tabular}

Forage nutrient quality and forage availability from any particular source in each grazing period were accounted for in the model. Seasonal variation in forage quality may be a binding constraint on animal production (Cook and Harris 1968). Total nutrient quality of range forage is highly correlated with the single variable of digestible protein (Cook et al. 1977). Minimum digestible protein requirements for the various livestock classes were included in the model to account for seasonal nutrient variations (National Research Council 1976, Cook and Harris 1968). Metabolizable energy requirements were also incorporated to assure adequate winter feed requirements are met. Maximum daily intake, however, was restricted to $2.3 \%$ of body weight to prevent unrealistic livestock feed intake values. After establishment, crested wheatgrass was an early season forage substitute for BLM and deeded native range forage. Unused $B L M$ and deeded native range forage was carried forward in the model one grazing period. For example, 50 deeded AUM's (Animal Unit Months) not consumed 15 May-14 June were available 15 June-14 July but were not available during the 15 June-14 September grazing period. 
In the analysis, an LP solution was initially obtained for the representative ranch having an adequate but low quality supply of early spring pasture. Based on activity levels of this solution, constraints for successive models were established. Seeding of crested wheatgrass then occurred on 1,012 ha of private rangeland. Seeding 1,012 ha results in a loss of 125 AUM's for 2 years of deferment following seeding. This 125 AUM's were based on 8.1 ha per AUM (Mitchell and Garrett 1977). Deeded land was assumed to be available for lease during these 2 years at a cost of $\$ 5.70$ per head per month, an average of values provided by a sample of Elko ranchers. This lease charge was the only additional cost accounted for as a result of seeding.

After successful conversion to crested wheatgrass, the 1,012 ha are assumed to provide 833 AUM's, or 1.24 ha per AUM, April 15-June 14 (a personal communication with R.A. Evans, range scientist, USDA, ARS, Reno, Nev.). A separate constraint was added to the model to account for the crested wheatgrass forage source. A crested wheatgrass stand life of 20 years, with constant annual production, was evaluated. Many factors influence productive life of a stand, but crested wheatgrass seedings have remained in use for 30 years or more (Hull 1972).

If an increase in herd size occurred in the ranch model following establishment of crested wheatgrass, heifer calf sales were reduced in years prior to availability of crested wheatgrass. Fewer weaner heifers were sold during year 2 to adjust herd size to the anticipated increased forage availability. These heifers mature and are productive at the time the seeding is available in year 4 .

Permanent increases in weaning weight and calving percentage were assumed to occur following seeding. Weaning weights increase by $9.07 \mathrm{~kg}(20 \mathrm{lb})$ per calf in the initial year of crested wheatgrass grazing. Calving percentage increases 5 percentage points during the second year of crested wheatgrass grass availability. These values may be conservative estimates of production increases attainable by seeding crested wheatgrass. Weaning weight inreases of $9.08 \mathrm{~kg}$ were assumed by Kearl and Cordingly (1975), and pasture research results of $10-16 \mathrm{~kg}$ were reported by Cook (1966) and Springfield (1963). Differences in calving percentages between native range and seeded pasture of $10-30 \%$ have been reported by Frischknecht (1965) and Houston and Urick (1972). Kearl and Cordingly (1975) assumed an $8 \%$ increase.

Although cattle production increases were assumed in this study as a result of improved forage availability, factors other than crested wheatgrass seeding may influence the amount, if any, of these increases. Livestock nutrition in the spring prior to seeding establishment may be at a level such that spring forage from crested wheatgrass will not affect animal production. Increases in calving percentages may result from cows and bulls grazing together in a more concentrated area rather than from the seeded pasture itself (Houston and Urick, 1972). Changes in stocking rates prior to and following seeding may also influence animal production response. For ranchers planning to expand existing range areas of crested wheatgrass, the impact on animal production will likely be less than if cattle change from a native forage only situation to a native forage and crested wheatgrass situation.

Changes in management practices and cattle production, which were assumed to occur from one year to the next during crested wheatgrass establishment, are shown in Table 4. These livestock production increases were assumed to be maintained throughout the life of the crested wheatgrass stand.

Differences between ranch net returns above variable costs prior to seeding and following seeding were calculated for each year. Present value of added net returns was then calculated to place all current and future costs and incomes on a comparable basis. Costs and incomes were discounted in the year they occurred.

A discount rate (r) of $6 \%$ was used. The average yield on U.S. Treasury bonds was approximately $12 \%$ (Wall Street Journal, April, 1984). The expccted rate of inflation was assumed to be $8 \%$ annually with a risk premium of $2 \%$ such that:
Table 4. Annual changes/actions made during seeding establishment.

\begin{tabular}{cl}
\hline \hline Year & \multicolumn{1}{c}{ Establishment action } \\
\hline 1 & $\begin{array}{l}\text { Year of seeding } 1012 \text { ha }(2500) \text { acres of crested wheatgrass; } \\
\text { cost of seeding incurred in fall. }\end{array}$ \\
2 & $\begin{array}{l}\text { Private pasture is leased to account for loss of } 125 \text { AUM's } \\
\text { of deeded range; and, lease cost incurred. If herd size in- } \\
\text { crease is anticipated following crested wheatgrass availa- } \\
\text { bility, fewer heifers are sold to build up herd size; lower } \\
\text { revenue from heifer sales; and deferment of crested wheat- } \\
\text { grazing. }\end{array}$
\end{tabular}

3 Lease cost incurred; increased grazing fees if heifers are being kept to mature as cows in anticipation of crested wheatgrass availability; deferment of crested wheatgrass grazing.

4 Crested wheatgrass available for grazing: cow herd increases (if possible) as heifers not sold in previous years are now mature; increased calf weaning weights of $9.07 \mathrm{~kg}$ per head.

$5 \quad$ Full benefits of crested wheatgrass realized as cow calving percentage increase of five percent is attained, along with calf weight increases.

$$
\begin{aligned}
& \mathrm{r}=12 \%-8 \%+2 \% \\
& r=6 \%
\end{aligned}
$$

This represents a real rate of interest because all per unit income and costs were in constant dollar values. Lower (higher) rates of discount, reflecting lower (higher) levels of risk or higher (lower) rates of inflation will yield higher (lower) net present values (NPV's) than those reported in this study.

\section{Results and Discussion}

Based on resource levels obtained from the initial optimal solution, net income impacts of varying resource levels upon profitability of seeding crested wheatgrass were examined. For the representative ranch with adequate spring forage, seeding crested wheatgrass was profitable, assuming calving percentage and weaning weight increases occurred (Table 5). Seeding allows delayed grazing of nonimproved range in a later season. Cow herd size was not expanded, however, because forage sources in other feeding periods were physically limiting and purchase of grass hay was not economical. Crested wheatgrass became an excess range forage source. Ranch net returns increased following seeding because of decreased BLM forage purchased, increased calving percentage, and increased weaning weights.

For comparison, the profitability of seeding crested wheatgrass with no assumed cattle production increases was also examined (Table 5). Seeding with no change in calf weight and calving percentage did not produce a positive NPV. This range improvement project was not profitable because crested wheatgrass was an excess forage source. With no cattle production increases assumed, the project produced no additional revenue, although it did reduce costs by decreasing BLM grazing purchased and hence, decreasing BLM grazing fees paid.

\section{Hayland Resources}

Amount of ranch hayland was varied $50 \%$ to determine the effect on profitability of seeding ranches that differ in relative quantities available of this forage source. As shown in Table 5, discounted added net returns from seeding were increased $13 \%$ on a ranch which has $50 \%$ greater meadow hayland ( 786 ha relative to the representative ranch situation of $524 \mathrm{ha}$ ). Ranches with relatively large meadow hayland resource levels have a source of low cost fall and winter forage enabling herd size to expand beyond the size limited in the "just adequate" initial forage case. With a $50 \%$ 
Table 5. Economic effects of crested wheatgrass seeding with varying forage resource availabilities on a representative ranch, Elko County, Nevada.

\begin{tabular}{|c|c|c|c|c|c|}
\hline \multirow{2}{*}{$\begin{array}{l}\text { Resource quantity } \\
\text { relative to } \\
\text { initial level }\end{array}$} & \multicolumn{2}{|c|}{ Net Ranch Income (\$) } & \multirow{2}{*}{$\begin{array}{l}\text { NPV of added net } \\
\text { returns @ 6\% disc } \\
\text { rate (20 Yrs.) }\end{array}$} & \multicolumn{2}{|c|}{ Cow herd size } \\
\hline & $\begin{array}{r}\text { Before } \\
\text { seeding }\end{array}$ & $\begin{array}{c}\text { After } \\
\text { seeding }\end{array}$ & & $\begin{array}{l}\text { Before } \\
\text { seeding }\end{array}$ & $\begin{array}{l}\text { After } \\
\text { seeding }\end{array}$ \\
\hline Seeding: & & & & & \\
\hline $\begin{array}{l}\text { With no cattle production } \\
\text { increases }\end{array}$ & $\$ 30,721$ & $\$ 31,765$ & $\$-39,796$ & 480 & 480 \\
\hline With cattle production increases & 30,721 & 44,884 & 60,720 & 480 & 480 \\
\hline $\begin{array}{l}\text { Meadow hayland: } \\
+50 \% \\
-50 \%\end{array}$ & $\begin{array}{l}30,721 \\
16,094\end{array}$ & $\begin{array}{l}47,055 \\
23,351\end{array}$ & $\begin{array}{r}68,624 \\
7,614\end{array}$ & $\begin{array}{l}480 \\
240\end{array}$ & $\begin{array}{l}505 \\
240\end{array}$ \\
\hline $\begin{array}{l}\text { Deeded range: } \\
+50 \% \\
-50 \%\end{array}$ & $\begin{array}{l}31,482 \\
20,019\end{array}$ & $\begin{array}{l}45,808 \\
30,924\end{array}$ & $\begin{array}{l}62,042 \\
31,278\end{array}$ & $\begin{array}{l}480 \\
317\end{array}$ & $\begin{array}{l}480 \\
330\end{array}$ \\
\hline $\begin{array}{l}\text { BLM range: } \\
+50 \% \\
-50 \%\end{array}$ & $\begin{array}{l}30,721 \\
17,535\end{array}$ & $\begin{array}{l}44,884 \\
37,294\end{array}$ & $\begin{array}{l}60,720 \\
57,969\end{array}$ & $\begin{array}{l}480 \\
264\end{array}$ & $\begin{array}{l}480 \\
394\end{array}$ \\
\hline
\end{tabular}

increase in meadow hay availability, full use of the seeding, and delayed seasonal use of native range forage enabled complete utilization of all forage resources. The increase in herd size of 25 head contributed to the largest positive NPV of added net returns obtained of investment scenarios examined.

A ranch with $50 \%$ less meadow hayland available ( $262 \mathrm{ha}$ ) than the representative operation had the lowest positive NPV of the seeding investment alternatives analyzed (Table 5). In this situation, the reduccd amount of low cost fall and winter feed, compared to the representative ranch, resulted in a smaller economically optimal herd size. Smaller herd size created an excess supply of crested wheatgrass and other range forage. Lower returns were obtained because of the smaller number of livestock sold. NPV was positive but low, relative to other alternatives evaluated in the study.

\section{Deeded Range}

A ranch with $50 \%$ greater deeded range capacity than the representative ranch yielded the second largest added NPV (Table 5). Increased net returns in this model were a result of reduced BLM grazing fees paid as more deeded land was a vailable. Herd size was not increased, however, due to the limited availability of all other forage sources, particularly meadow hayland. Purchase of grass hay was not profitable in this model.

The $50 \%$ smaller deeded range capacity yielded lower, but positive added net returns compared to the increased deeded forage operation. Although operations were assumed to have equal maximum quantity of BLM forage available, the smaller amount of available deeded range limited the amount of BLM forage used, causing a smaller optimal herd size. Crested wheatgrass became a complementary forage source for the $50 \%$ lower deeded capacity by enabling deferred use of deeded land later in the grazing season. This a vailability of later forage, with crested wheatgrass providing early season grazing, enabled expansion of herd size by 23 cows (Table 5).

\section{BLM Range}

Under model assumptions, $50 \%$ more BLM forage available had no effect on NPV of the investment, all else constant (Table 5). No herd size difference existed due to equal hay resources. A larger amount of public rangeland, other forage source quantities equal, did not alter the profitability of crested wheatgrass relative to the representative ranch case. The additional BLM forage was not purchased.

Fifty percent less BLM forage available, accompanied by crested whcatgrass sceding, yielded NPV of added returns slightly less than those obtained in the representative ranch model (Table 5). A herd size increase of 130 head occurred after the investment was made. Because $32 \%$ of the ranch's spring and summer forage was supplied by public range, seeding crested wheatgrass became a profitable complement to this forage source. As in the case of limited deeded range, deferred BLM forage use combined with spring crested wheatgrass availability enabled additional grazing. Herd size expansion was possible because other resources, at the representative ranch level of availability, were in excess supply prior to seeding.

\section{Summary and Conclusions}

Based on NPV investment criterion and assumptions made in this study, removing sagebrush and seeding crested wheatgrass was a profitable investment for a representative Elko County, Nev., cow-calf operation. The degree of profitability, however, was influenced by the a vailability of certain other ranch forage sources. Availability of relatively low-cost winter feed (ranch produced meadow hay) had the largest impact upon profitability of the investment. An excess amount of this resource enables herd size to expand and fully utilize the new forage source. NPV of the investment also increases, if excess deeded range is available.

Increases in calf weaning weights and calving percentages were assumed to occur as a result of cattle grazing the improved forage source. Production increases assumed in this study should be realistic objectives for many cow-calf operators. If high levels of management and nutrition are provided before seeding, these increases in animal production may not be achieved.

An opcrator considering investment in crested wheatgrass to provide early spring forage should consider herd size adjustments desirable during years of seeding establishment. This analysis assumed additional deeded land was available for lease to maintain herd size prior to availability of the seeding. If additional land is not available, other feed sources may be too costly for crested wheatgrass to be a profitable investment.

\section{Literature Cited}

Cook, C.W. 1966. Development and use of foothill ranges in Utah. Utah State Univ. Agr. Exp. Sta. Bull. 461.

Cook, C.W., and L.E. Harris. 1968. Effect of supplementation on intake and digestibility of range forage. Utah Statc Agr. Exp. Sta. Bull. 475.

Cook, C.W., D.R. Child, and L.L. Larson. 1977. Digestible protein in range forages as an index to nutrient content and mineral response. Colorado State Dep. Kange Sci. Series 29.

Cunha, T.J., A.C. Warnick, and M. Koger. 1967. Factors affecting calf crop. University of Florida Press, Gainesville.

D'Aquino, S.A. 1974. A case study for optimal allocation of range resources. J. Range Manage. 27:228-232. 
Day, R.H. 1963. Recursive programming and production response. NorthHolland Publishing Co., Amsterdam.

Dewey, D.R., and K.H. Asay. 1975. The crested wheatgrass of Iran. Crop Sci. 15:844-849.

Frischknecht, N.C. 1965. The Benmore experimental range. Intermountain Forest and Range Exp. Sta. Pub.

Frischknecht, N.C., L.E. Harris, and H.K. Woodward. 1953. Cattle gains and vegetal changes as influenced by grazing treatments on crested wheatgrass. J. Range Manage. 6:151-158.

Godfrey, E.B. 1979. Utilization practices and the returns from seeding an area to crested wheatgrass. J. Range Manage. 32:171-174.

Godfrey, E.B., L.A. Sharp, and E. Sellasie. 1979. The economic returns from seeding an area to crested wheatgrass. Univ. of Idaho Agr. Exp. Sta. Bull. No. 588.

Hart, R.H., J.W. Waggoner, Jr., D.H. Clark, C.C. Kaltenbach, J.A. Hager, and M.B. Marshall. 1983. Beef cattle performance on crested wheatgrass plus native range vs. native range alone. J. Range Manage. $36: 38-40$.

Houston, W.R., and J.J. Urick. 1972. Improved spring pastures, cow-calf production and stocking ratc carryover in the northern Great Plains. USDA Tech. Bull, 1451 .

Hull, A.C. Jr. 1972. Growth characteristics of crested and fairway wheatgrasses in Southern Idaho. J. Range Manage. 25:123-125.

Jeffries, N.W., R.L. Lang, M. May, and L. Landers. 1967. Cow-calf production on seeded and native range. Wyoming Agr. Exp. Sta. Bull. 472.

Kearl, W.G., and R.V. Cordingly. 1975. Cost and returns from reseeding plains ranges in Wyoming. J. Range Manage. 28:437-441.

Lloyd, R.D., and C.W. Cook. 1960. Seeding Utah's ranges-An economic guide. Utah State Univ. Agr. Exp Sta. Bull 423.

Mitchel], B., and J.R. Garrett. 1977. Characteristics of the range cattle industry, 1972, Region III, Northeastern Nevada. Univ. of Nevada B42.

Myer, G.L., and I.E. Hackett. 1981. Costs and returns for cow-calf enterprise in Elko County, Nevada. Univ. of Nevada Coop. Ext. Service Economic Fact Sheet E-29-81.
National Research Council. 1976. Nutrient requirements of beef cattle. No. 4. Fifth revised ed. National Academy of Sciences, Washington, DC.

Rauzi, F. 1975. Seasonal yield and chemical composition of crested wheatgrass in Southeastern Wyoming. J. Range Manage. 28:219-221.

Robertson, J.H., D.L. Neal, K.R. McAdams, and P.T. Tueller. 1970. Changes in crested wheatgrass under different grazing treatments. J. Range Manage. 23:27-34.

Sharp, L.A. 1970. Suggested management programs for grazing crested wheatgrass. Univ. of Idaho Forest, Wildlife and Range Exp. Sta. Bull. No. 4.

Sonnemann, D.W. 1982. An analysis and application of recursive linear programming on a ranch organization considering crested wheatgrass as a range improvement. M.S. Thesis, Univ. of Nevada, Reno.

Sonnemann, D.W., R.L. Shane, R.A. Evans, and J.A. Young. 1981. Crested wheatgrass production costs for Northern Nevada. Univ. of Nevada Coop. Ext. Service Economic Fact Sheet E-28-81.

Springfield, H.W. 1963. Cattle gains and plant responses from spring grazing on crested wheatgrass in Northern New Mexico. USDA Prod. Res. Rep. No. 74.

Torell, L.A., J.R. Garrett, and C.T.K. Ching. 1981. The cconomic effcets of three changes in public lands grazing policies. J. Range Manage. 34:373-376

U.S.D.A. 1979-1981. Livestock and Meat Outlook. Economic Research Service. Washington, D.C.

U.S.D.A. 1983. Agricultural Prices. Statistical Reporting Service. Washington, D.C.

Wall Street Journal. Bills, bonds and notes. April 27, 1984.

Woodworth, B.M. 1973. Optimizing the calf mix on rangelands with linear programming. J. Range Manage. 26:175-178.

Young, J.A., R.E. Eckert, Jr., and R.A. Evans. 1979. Historical perspectives regarding the sagebrush ecosystem. p. 1-13. In: The Sagebrush Ecosystem: A Symposium. Utah. State University, College of Natural Resources, Logan, Utah.

\title{
RANGELAND HYDROLOGY
}

\author{
by Farrel A. Branson, Gerald F. Gifford, Kenneth G. Renard, and \\ Richard F. Hadley
}

Unique in its emphasis on the hydrology of rangelands, primarily arid and semiarid lands. RANGELAND HYDROLOGY provides a text for one aspect of range management where none has existed before. This expanded Second Edition presents in-depth information for those who must manage rangeland or respond to questions about the impacts of land use practices on hydrology.

Included in the new Second Edition are a chapter on modeling with approaches to predicting the effects of land use, and a chapter on the rapidly developing field of snow pack management:

The 352-pages include 197 illustrations, providing rapid access to an assembly of data found nowhere else and useful in the preparation of environmental impact statements. Extensive bibliographic material with each chapter and a subject matter index add to the useableness of the book.

Range scientists and managers, soil conservationists, hydrologists, agricultural engineers, land reclamation specialists, wildlife managers, graduate and undergraduate students and their professors, as well as all interested in the hydrology of arid lands will find RANGELAND HYDROLOGY a valuable addition to their libraries. (352 pages paper laminated cover $\$ 15.00$ US) 